\title{
ANTIBACTERIAL ACTIVITY OF FLAVONOID FROM KEPEL (STELECHOCARPUS BURAHOL) LEAVES AGAINST STAPHYLOCOCCUS EPIDERMIDIS
}

\author{
SUSI INDARIANI ${ }^{1}$, AISYAH HIDAYAT ${ }^{2}$, LATIFAH K DARUSMAN ${ }^{1,2}$, IRMANIDA BATUBARA ${ }^{1,2^{*}}$ \\ ${ }^{1}$ Tropical Biopharmaca Research Center, Bogor Agricultural University, Bogor 16128, Indonesia, ${ }^{2}$ Department of Chemistry, Bogor \\ Agricultural University, Bogor 16151, Indonesia \\ Email: ime@apps.ipb.ac.id
}

Received: 11 Apr 2017 Revised and Accepted: 31 Aug 2017

\begin{abstract}
Objective: The objective of this research was to separate flavonoids of kepel (Stelechocarpus burahol) leaves from methanol extract as antibacterial agent against Staphylococcus epidermidis that have a role in body odor.

Methods: The methanol extracts of kepel was fractionated in methanol: water (7:3), $n$-hexane and chloroform consecutively. Methanol: water (7:3) extract with the highest flavonoids content, fractioned by silica gel column chromatography (isocratic elution, with $n$-buthanol: methanol: acetic acid (1:8:1) as eluent) to produce 7 fractions. All fractions were tested for antibacterial activity with a microdilution method. The most active fractions was determined using UV-VIS spectrophotometer (Shimadzu, Japan) and FTIR (Brucker, Germany).

Results: Fraction $\mathrm{V}$ was the most active fraction with minimum inhibitory concentration (MIC) $0.06 \mathrm{mg} / \mathrm{ml}$ and minimum bactericidal concentration (MBC) of $0.50 \mathrm{mg} / \mathrm{ml}$. Fraction $\mathrm{V}$ was further separated by preparative thin layer chromatography (TLC) and gave three fractions. Fraction V3 was the most active fraction with MIC $1.00 \mathrm{mg} / \mathrm{ml}$ and $\mathrm{MBC}$ of $2.00 \mathrm{mg} / \mathrm{ml}$. Identification of fraction V3 based on assessments on ultraviolet-visible and infrared spectrum showed the maximum wavelength at $327 \mathrm{~nm}$. These results indicate a transition $\pi \rightarrow \pi^{*}$ and $\mathrm{n} \rightarrow \pi^{*}$ generated from the chromophore conjugated $\mathrm{C}=\mathrm{C}$ and $\mathrm{C}=0$. Based on the allegations of the functional group obtained, then alleged that in Fraction V3 containing flavones compounds.
\end{abstract}

Conclusion: These results suggest that flavonoid of $S$. burahol leaves extracts is potential as antibacterial agents against S. epidermidis and therefore justifies their usage in traditional medicine for the treatment of body odor.

Keywords: Fractionation, Flavonoid, Stelechocarpus burahol, Antibacterial, Staphylococcus epidermidis

(C) 2017 The Authors. Published by Innovare Academic Sciences Pvt Ltd. This is an open access article under the CC BY license (http://creativecommons.org/licenses/by/4.0/) DOI: http://dx.doi.org/10.22159/ijpps.2017v9i10.19071

\section{INTRODUCTION}

Axillary body odor is individually specific and potentially a rich source of information about its products. Odor individuality partly results from genetic individuality, but the influence of ecological factors such as eating habits are another main source of odor variability [1]. The generation of malodour on various sites of the human body is caused by the microbial biotransformation of odourless natural secretions into volatile odorous molecules. On the skin surface, distinctive odours emanate, in particular, from the underarm (axilla), where a large and permanent population of microorganisms thrives on secretions from the eccrine, apocrine and sebaceous glands [2]. The sweat issued by someone very involved in the onset of body odor. Infection of the apocrine glands that produce sweat by bacteria, can play a role in the decay process. Bacteria induced the body odor are Staphylococcus epidermidis, Corynebacterium acne, Pseudomonas aeruginosa, and Streptococcus pyogenes [3]. Several herbals have been used as deodorant to treat axillary body odor.

Kepel (Stelechocarpus burahol (Blume) Hook. f. and Thomson) is one of fruit tree originally found in Indonesia, included in the family Annonaceae. Kepel is a plant that has been used traditionally as a fragrance especially among the palaces in Indonesia. Part of the plant used for medicinal are leaves, bark and fruit [4]. Consumed the fruit can reduce the smell of sweat, breath and urine [4]. It was reported that fuit pulp had potential as a natural deodorant since it had adsorbent function and probiotic activation by increase the growth of Bifidobacteria so the population of odorant producing bacteria will be reduced [5]. The fruit pulp of kepel also reported contains high antioxidant [6], and contains alkaloids, flavonoids, polyphenols, triterpenoids, saponins and quinones as well have the effect of anti-implantation [7]. Kepel's leaf contains terpenoids and flavonoids [7]. Leaves extracts of kepel contains flavonoids include auron, flavanones and flavanols that can be used for antibacterial [9]. Ethanol and $n$-hexane extracts of kepel's leaf has potential for lowering uric acid levels in mice [10,11]. Phenylalanine ammonia lyase (PAL) enzyme activity and anthocyanins content in young leaves were relatively higher than the mature and the medium leaves, but mature kepel leaves have the highest flavonoid content and total chlorophyll than others. Increased rainfall will decrease the content of flavonoid in kepel leaves, but increased anthocyanin, PAL activity and total chlorophyll. Therefore kepel mature leaves can be used as raw material for medicine [12].

Utilization of antibiotics will usually make the bacteria become resistant and permanent nature multiplies within its host. Therefore, it is necessary to investigate the antibacterial active compounds in kepel leaves extracts that capable to inhibit $S$. epidermidis growth. This study aimed to identify the flavonoid from kepel leaves extract that has potential as an antibacterial against $S$. epidermidis. $S$. epidermidis is one of the suspected bacteria that cause body odor. Furthermore, S. epidermidis are generally resistant to penicillin, amoxicillin and methicillin [13], so it's very important to investigate alternative compounds that can inhibit the growth of this bacteria.

\section{MATERIALS AND METHODS}

\section{Collection of plant material}

Stelechocarpus burahol leaves were collected in April 2011 from Cilacap, Central of Java, Indonesia. The plant identification and authentication certificate issued by the Herbarium LIPI. Voucher specimen (No. voucher specimen: BMK0199092016) is deposited at Tropical Biopharmaca Research Center, Bogor Agricultural University, Indonesia. The leaves taken from plant of kepel 3 y old, and mixed among the young leaves and old leaves. The materials were washed, wet sortation, dried at $50{ }^{\circ} \mathrm{C}$ in oven dryer and grinded into powder. 


\section{Chemicals and reagents}

All chemicals were purchased from Sigma-Aldrich Co., Inc. (St. Louis, MO, USA). All solvents used were of HPLC grade, obtained from EMerck Ltd. (Darmstadt, Germany). The chromatography plates were TLC aluminium plated precoated with silica gel $60 \mathrm{PF}_{254}(20 \times 10 \mathrm{~cm}$, $0.2 \mathrm{~mm}$ thick) obtained from E-Merck Ltd. (Darmstadt, Germany). The test organism used in this study was Staphylococcus epidermidis ATCC 12228. Bacterial culture agar and broth were purchased from E-Merck Ltd. (Darmstadt, Germany). Tetracycline and trichlorocarbon (TCC) were purchased from Pharmaceutical Company (Jakarta, Indonesia).

\section{Extract preparation and fractionation}

Extraction was preformed according to the methods of Sukadana with a little modification [14]. The dried leaves powder of kepel was macerated with methanol $(1 \mathrm{~g}$ dried leaf powder: $10 \mathrm{ml}$ methanol, $\mathrm{w} / \mathrm{v}$ ) for $24 \mathrm{~h}$ at room temperature. Solvent was evaporated by rotary evaporator.

The methanol extract of kepel leaves was suspended in methanol: water $(7: 3)$ mixture and then partitioned with $25 \mathrm{ml} n$-hexane. The layer of extract suspended in $n$-hexane was evaporated, while the methanol: water partitioned again with $25 \mathrm{ml}$ chloroform in order to get the methanol: water extracts and chloroform extracts. Each of the extract was evaporated to remove the solvent and analyzed with flavonoid phytochemical test [15]. Methanol: water (7:3) extract with the highest flavonoids content, fractioned by silica gel column chromatography (isocratic elution, with $n$-buthanol: methanol: acetic acid (1:8:1) as eluent) to produce 7 fractions. Fractions that showed similar $R_{f}$ value and TLC profile were combined. All fractions were tested for antibacterial activity with a microdilution method. The fraction that has the highest antibacterial activity further separated using TLC preparative to obtain the most active fractions.

\section{Antibacterial assay}

Antibacterial assay was perfomed by following procedure of Batubara et al. [16]. The test organism used in this study was Staphylococcus epidermidis ATCC 12228. The medium used in this study was trypticase soy broth (TSB). Sterilized medium $(100 \mu \mathrm{l})$, sample [40 $\mu$, serial concentration, diluted in dimethylsulfoxide (DMSO) $20 \%$ ] or positive control $(40 \mu \mathrm{l})$, and inoculum $(5 \mu \mathrm{l})$ were added to each well of a 96-well plate. The inoculum was prepared at the concentration of $10^{-2} \mathrm{CFU} / \mathrm{ml}$. S. epidermidis was incubated in the medium for $48 \mathrm{~h}$ at $37^{\circ} \mathrm{C}$. The extract concentration at which there was no visually detectable bacterial growth was described as the minimum inhibitory concentration (MIC). Next, $10 \mu \mathrm{l}$ of each medium with no visually detectable bacterial growth was inoculated in $100 \mu \mathrm{l}$ of fresh medium for $48 \mathrm{~h}$ at $37^{\circ} \mathrm{C}$. The concentration at which there was no bacterial growth after the second inoculation was described as the minimum bactericidal concentration (MBC). The positive controls used were tetracycline and TCC. The antibacterial assay was conducted a minimum of three times, each at different times.

\section{Determination active compounds}

Determination of compounds contained in the most active fractions was performed using UV-VIS spectrophotometer (Shimadzu, Japan) and FTIR (Brucker, Germany).

\section{RESULTS AND DISCUSSION}

\section{Extraction and investigation of flavonoid content in leaf extracts}

Extraction was made with methanol as a solvent, referring to the polar nature of methanol in extracting the flavonoid compound. Generally, flavonoids are soluble in polar solvents such as ethanol, methanol, $n$-buthanol, acetone, dimethyl sulfoxide, and water. The presence of sugar bound to the flavonoid cause flavonoids more soluble in water [17]. Maceration process is particularly advantageous in the isolation of natural compounds because in the immersion will occur break down cell walls and membranes cell. This happens due to the pressure difference between the inside and outside of the cell, so that the secondary metabolites present in the cytoplasm will be dissolved in a solvent. The yield of leaf extracts was $15.15 \%(w / w)$.

The methanol extract of the leaves was separated by a liquid-liquid extraction. This leads to mass transfer from the originating solvent to the solvent extraction. Polar components will be distributed on a methanol: water, semipolar components will be distributed in chloroform, and nonpolar components will be distributed on $n$ hexane. The components that distributed in $n$-hexane and chloroform are fat, terpenes, chlorophyll, and xantofil [17]. The yield of $n$-hexane, chloroform and methanol: water extract obtained from the leaf extracts were $31.98,11.81$, and $27.82 \%(\mathrm{w} / \mathrm{w})$ respectively. The yield of $n$-hexane extract higher compared to the other showed in the leaf of kepel contain nonpolar components. Based on qualitative flavonoid test, methanol: water extracts have the high flavonoid content. $n$-Hexane extract has no flavonoids content (table 1). Flavonoids are hydroxylated phenolic substances known to be synthesized by plants in response to microbial infection and they have been found to be antimicrobial substances against a wide array of microorganisms in vitro. Several flavonoids, including flavones such as apigenin, flavonols such as galangin, flavonol glycosides, isoflavones, flavanones, and chalcones have been shown to possess potent antibacterial activity [18]. Flavonoids have the ability to complex with proteins and bacterial cells mainly with nucleophilic amino acids. This complex often leads to inactivation of the protein and loss of its functionality [19].

Table 1: Flavonoid present in leaves extracts of $S$. burahol

\begin{tabular}{ll}
\hline Extracts & Results \\
\hline$n$-hexane & - \\
Chloroform & + \\
Methanol: Water $(7: 3)$ & +++ \\
\hline
\end{tabular}

+indicating positive test and-indicating negative test

\section{Antibacterial activity}

The methanol: water extracts have the high flavonoid content, so this extract fractioned by silica gel column chromatography (isocratic elution, with $n$-buthanol: methanol: acetic acid (1:8:1) as eluent). Fractions that eluted be precious on column chromatography separation showed antibacterial activity (table 2). Fraction $\mathrm{V}$ is the most active fraction with MIC of $0.06 \mathrm{mg} / \mathrm{ml}$ and $\mathrm{MBC}$ of $0.50 \mathrm{mg} / \mathrm{ml}$. The MIC and MBC value of fraction $\mathrm{V}$ is equal to tetracycline that means the antibacterial activity of Fraction $\mathrm{V}$ and tetracyclines are same. When compared with the TCC, the Fraction V had higher activity than TCC. Tetracycline and TCC are a group of broad-spectrum anti-infective used commercially in soaps, shampoos, deodorants and other household products.
Fraction $\mathrm{V}$ as the most active fraction is a mixture of 3 spot, thus further separated using preparative TLC with $n$-buthanol: acetic acid: water $(4: 1: 5)$ to separate the flavonoid [17]. Based on the separation obtained three fractions. All fractions subjected to antibacterial assay. The results showed the fraction V3 was the most active fraction compared with other fractions (table 3). The MIC and MBC value of Fraction V3 was higher than tetracycline and TCC, which means the fraction V3 has a lower activity than tetracycline and TCC. Activities Fraction V higher than the Fraction V3, it is suspected that there were several compounds mixed in Fraction $\mathrm{V}$ are potential as antibacterial. The complex mixtures of Fraction $V$ composed mainly of flavonoid caused a synergistic effect as antibacterial against $S$. epidermidis. MIC is the lowest concentration of an antimicrobial inhibit the visible growth of a microorganism. 
MICs are important in diagnostic laboratories to confirm resistance of microorganisms to an antimicrobial agent and also to monitor the activity of new antimicrobial agents [20]. Aligiannis et al. [21], classifying extracts of plant material on the basis of MIC is as follows: -strong inhibition: MIC $<500 \mu \mathrm{g} / \mathrm{ml}$; -Moderate inhibition: MIC from $500 \mu \mathrm{g} / \mathrm{ml}$ to $1500 \mu \mathrm{g} / \mathrm{ml}$; -Weak inhibition: MIC>1500 $\mu \mathrm{g} / \mathrm{ml}$. Therefore, antibacterial activity of methanol: water (7:3) extract and the fractionation results included in strong inhibition classification.

Table 2: Antibacterial activity of fractionation I-VII from silica gel column chromatography

\begin{tabular}{|c|c|c|}
\hline Fraction name & MIC (mg/ml) & MBC (mg/ml) \\
\hline $\mathrm{I}$ & 2.00 & $>2.00$ \\
\hline II & 0.12 & 2.00 \\
\hline III & 0.25 & 1.00 \\
\hline IV & 0.25 & 2.00 \\
\hline V & 0.06 & 0.50 \\
\hline VI & $>2.00$ & $>2.00$ \\
\hline VII & $>2.00$ & $>2.00$ \\
\hline Tetracycline* & 0.06 & 0.50 \\
\hline TCC* & 0.12 & 1.00 \\
\hline
\end{tabular}

*positive control

Table 3: Antibacterial activity of TLC preparative fraction

\begin{tabular}{lll}
\hline Fraction name & MIC $(\mathbf{m g} / \mathbf{m l})$ & MBC $(\mathbf{m g} / \mathbf{m l})$ \\
\hline FractionV1 & 2.00 & $>2.00$ \\
Fraction V2 & 2.00 & $>2.00$ \\
Fraction V3 & 1.00 & 2.00 \\
Tetracycline ${ }^{*}$ & 0.06 & 0.50 \\
TCC* & 0.50 & 1.00 \\
\hline
\end{tabular}

*positive control

\section{Bioactive compounds}

Fraction V3 (the most active fraction) were obtained from the preparative TLC analyzed using UV-VIS spectrometer. Imaging was done with the wavelength changes of $2 \mathrm{~nm}$. The results of the UV-Vis analysis showed Fraction V3 has a maximum wavelength at $327 \mathrm{~nm}$. UV-VIS spectrum of Fraction V3 is shown in fig. 1. These results indicate a transition $\pi \rightarrow \pi^{*}$ and $\mathrm{n} \rightarrow \pi^{*}$ generated from the chromophore conjugated $\mathrm{C}=\mathrm{C}$ and $\mathrm{C}=0$. Compounds that have the transition $\pi \rightarrow \pi^{*}$ and $n \rightarrow \pi^{*}$ will absorb light in the UV region at a wavelength of 200-400 nm [22]. Absorption at 200-400 nm indicated the presence of chromophore group, which is one of the characteristics of flavones [23]. According to Markham [17], the maximum wavelength range $310-350 \mathrm{~nm}$ is the flavonoid class of flavone.

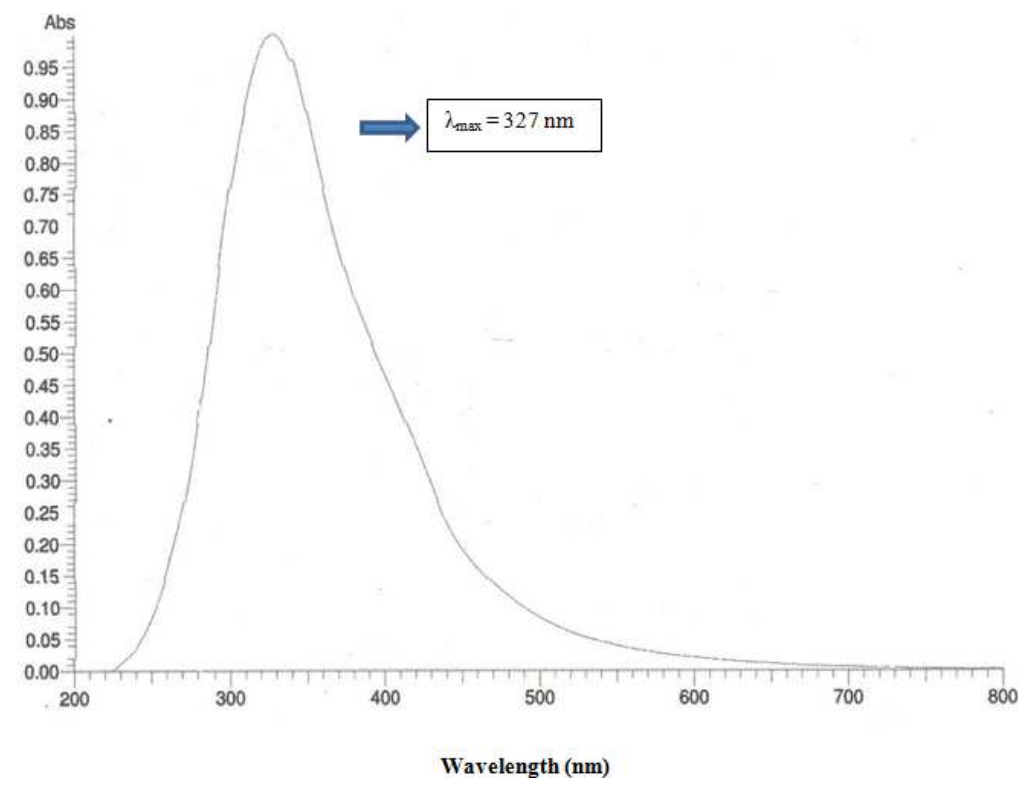

Fig. 1: UV-VIS spectrum of fraction V3

FTIR spectrum of Fraction V3 can be seen in table 4 and fig. 2. Based on the FTIR spectrum of Fraction V3 contain some functional groups such as-OH $\left(3406.00 \mathrm{~cm}^{-1}\right)$ which is supported also by the emergence of regional absorption at wavenumber $1109.55 \mathrm{~cm}^{-1}$ to $\mathrm{C}$ -
O bond. Aliphatic stretching C-H appeared at $2924.11 \mathrm{~cm}^{-1}$ and is reinforced by the presence of bending regional absorption at wave numbers $1398.31 \mathrm{~cm}^{-1}$. The functional groups of the $\mathrm{C}=\mathrm{C}$ aromatic demonstrated by the presence of regional absorption at wave 
number $1628.59 \mathrm{~cm}^{-1}$ and there is a stretching $\mathrm{C}=0$ at $1735.83 \mathrm{~cm}^{-1}$ region. Based on the allegations of the functional groups obtained, then alleged that in Fraction V3 containing flavone compounds (fig. 3). Hazra et al. [24] reported pentahydroxy flavones from the seeds of Mimusops elengi Linn showed strong inhibitory activity against
Gram positive and Gram negative bacteria. The flavonoid class of flavone from kepel leaves also reported by Sunarni et al. [25] as DPPH scavenger. They were identified flavon with hydroxyl group on C-3, C-7, C-3', C-4' and methyl on C-5 and showed activity with an $\mathrm{EC}_{50}$ value of $6.43 \mu \mathrm{g} / \mathrm{ml}$

Table 4: FTIR characteristic bands of fraction V3

\begin{tabular}{lll}
\hline Wave numbers $\mathbf{( \mathbf { c m } ^ { - 1 } )}$ & References* & Functional groups \\
\hline 3406.00 & $3200-3450$ & stretch O-H \\
2924.11 & $2850-3000$ & stretch C-H aliphatic \\
1628.59 & $1500-1675$ & stretch C=C aromatic \\
1735.83 & $1650-1900$ & stretch C=0 \\
1398.31 & $1300-1475$ & bend C-H aliphatic \\
1109.55 & $1000-1300$ & stretch C-O \\
\hline
\end{tabular}

*Sources: Creswell et al. [22] and Field et al. [26]

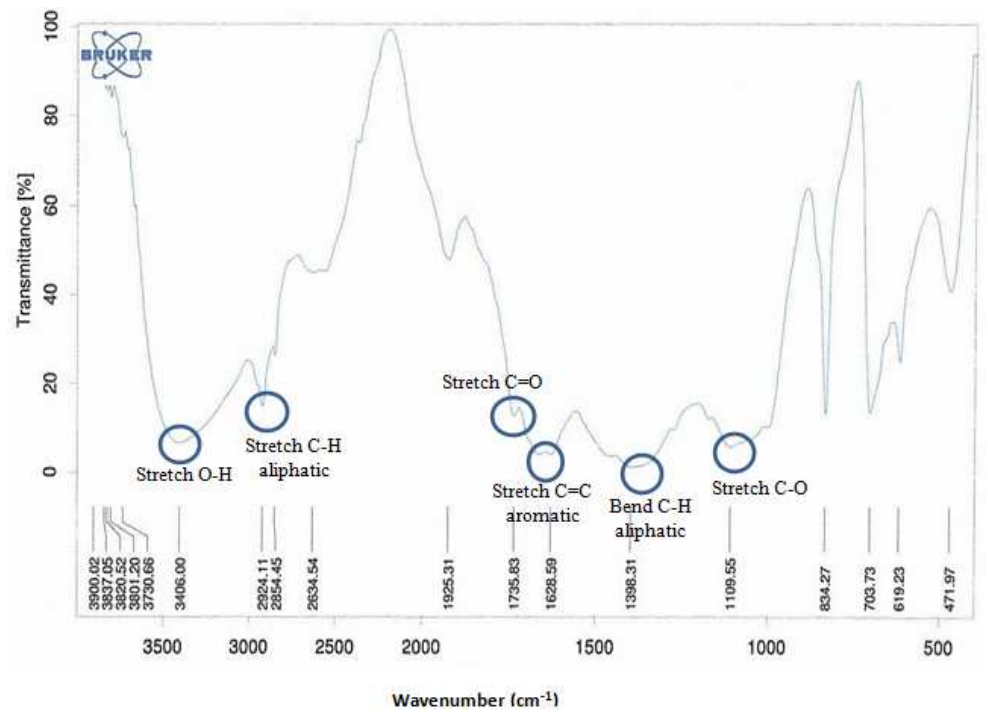

Fig. 2: FTIR spectrum of fraction V3<smiles>O=c1cc(-c2ccccc2)oc2ccccc12</smiles>

Fig. 3: Structure of flavone compounds

\section{CONCLUSION}

The fractionation of methanol: water (7:3) extract from kepel leaves with isocratic elution ( $n$-buthanol: methanol: acetic acid 1:8:1) using column chromatography resulted 7 fractions. V3 fraction is the most active with MIC $1.00 \mathrm{mg} / \mathrm{ml}$ and MBC $2.00 \mathrm{mg} / \mathrm{ml}$. The identification results using UV-VIS and FTIR alleged that the active compounds as antibacterial is flavone group.

\section{ACKNOWLEDGEMENT}

The authors would like to acknowledge the financial support for the project received from Tropical Biopharmaca Research Center, Bogor Agricultural University, Indonesia.

\section{AUTHOR CONTRIBUTION}

Susi Indariani, Aisyah Hidayat, Latifah K Darusman and Irmanida Batubara contributed equally in collection of plant material, experiment design, performing the experiment and data compilation. All of the authors wrote, read and approved the final manuscript.

\section{CONFLICTS OF INTERESTS}

All authors have none to declare

\section{REFERENCES}

1. Havlicek J, Lenochova P. The effect of meat consumption on body odor attractiveness. Chem Senses 2006;31:747-52.

2. James AG, Austin CJ, Cox DS, Taylor D, Calvert R. Microbiological and biochemical origins of human axillary odour. FEMS Microbiol Ecol 2013;83:527-40.

3. Endarti, Sukandar EY, Soediro I. Study of usnic acid activity against bacteria that cause body odor. J Bahan Alam Indonesia 2004;3:151-7.

4. Heyne K. The Useful Indonesian Plants. Jakarta (Indonesia): Research and Development Agency, Ministry of Forestry; 1987.

5. Darusman HS, Rahminiwati M, Sadiah S, Batubara I, Darusman LK, Mitsunaga T. Indonesian kepel fruit (Stelechocarpus burahol) as oral deodorant. Res J Med Plant 2012;6:180-8.

6. Tisnadjaja D, Saliman E, Silvia, Simanjuntak P. Assessment of burahol (Stelechocarpus burahol (Blume) hook and Thomson) as fruit contains antioxidant compounds. Biodiversitas 2006;7:199-202.

7. Suparmi S, Isradji I, Yusuf I, Fatmawati D, Ratnaningrum IH, Fuadiyah S, et al. Anti-implantation activity of kepel (Stelechocarpus burahol) pulp ethanol extract in female mice. J Pure Appl Chem Res 2015;4:94-9.

8. Aziz SA, Ramadhan BC. Media and organic fertigation for growth and phytochemical properties of Stelechocarpus burahol in nursery. In: Rizal M, Widyastuti Y, Brotokardono L, 
Efendi R, Rohadi D, Herwati T, Januawati NM. editors. International Seminar Proceedings Forests and Medical Plants for Better Human Welfare. Indonesia: Center for Forest Productivity Research and Development; 2014. p. 200-4.

9. Hidayat A, Darusman LK, Batubara I. Fractination of the active compound from kepel (Stelechocarpus burahol) leaf extract as antibacterial. In: Wijaya CH, Ahcmadi SS, Suparto IH, Batubara I, Rukayadi Y, Sulistyani, Rafi M, Darusman LK. editors. The 2nd International Symposium on Temulawak. Indonesia: Biopharmaca Research Center; 2011. p. 112-3.

10. Purwantiningsih, Purwantini I, Santoso D. Identification of standard parameters of kepel leaves (Stelechocarpus burahol (Bl.) Hook. F. and Th.) and the extract as raw material for antihyperuricemic medicaments. Asian J Pharm Clin Res 2011;4:149-53.

11. Sunarni T, Leviana F, Fidrianny I, Immaculata M, Wirasutisna KR. Antihyperuricemic and xanthine oxidase inhibitory activities of fractions from ethanolic leaves extract of Stelechocarpus burahol. Asian J Pharm Clin Res 2016;9:255-8.

12. Ramadhan BC, Aziz SA, Ghulamahdi MG. Potential bioactive content of kepel leaves (Stelechocarpus burahol). Bul Littro 2015;26:99-108.

13. Gill SR, Fouts DE, Archer GL, Mongodin EF, DeBoy RT, Ravel J, et al. Insights on evolution of virulence and resistance from the complete genome analysis of an early methicillin-resistant Staphylococcus aureus strain and a biofilm-producing methicillin-resistant Staphylococcus epidermidis strain. J Bacteriol 2005;187:2426-38.

14. Sukadana IM. Flavonoid compound from sweet star fruit (Averrhoa carambola Linn L) as antibacterial. J Kimia 2009;3:109-16.

15. Harborne JB. Phytochemical methods. 2nd ed. London (England): Chapman and Hall; 1984.

16. Batubara I, Mitsunaga T, Ohashi H. Screening antiacne potency of Indonesia medicinal plant: antibacterial, lipase inhibitor and antioxidant activities. J Wood Sci 2009;55:230-5.
17. Markham KR. Techniques of flavonoid identification. London: Academic Press; 1982.

18. Shashank K, Pandey AK. Chemistry and biological activities of flavonoids: an overview. Sci World J 2013;1-16. http://dx.doi.org/10.1155/2013/162750

19. Shimada T. Salivary proteins as a defense against dietary tannins. J Chem Ecol 2006;32:1149-63.

20. Andrews JM. Determination of minimum inhibitory concentrations. J Antimicrob Chemother 2001;48(Suppl 1):516.

21. Aligiannis N, Kalpotzakis E, Mitaku S, Chinou IB. Composition and antimicrobial activity of the essential oils of two origanum species. J Agric Food Chem 2001;40:4168-70.

22. Creswell CJ, Runquist OA, Campbell MM. Spectral analysis of organic compound. An introductory programmed text. Harlow London: Longman; 1972.

23. Alawiyah AL, Achmadi SS, Syahbirin G. Total phenolic content and flavone bioactivity of peanut hulls as antioxidant and antiproliferation toward Henrietta Lacks cancer cells. Asian J Pharm Clin Res 2017;10:144-9.

24. Hazra KM, Roy RN, Sen SK, Laskar S. Isolation of antibacterial pentahydroxy flavones from the seeds of Mimusops elengi Linn. Afr J Biotechnol 2007;6:1446-9.

25. Sunarni T, Pramono S, Asmah R. Antioxidant-free radical scavenging of flavonoid from the leaves of Stelechocarpus burahol (Bl.) Hook f. and Th. Majalah Farmasi Indonesia 2007;18:111-6.

26. Field LD, Sternhell S, Kalman JR. Organic structures from spectra. $3^{\text {rd }}$ ed. England: John Wiley and Sons; 2002.

\section{How to cite this article}

- $\quad$ Susi Indariani, Aisyah Hidayat, Latifah K Darusman, Irmanida Batubara. Antibacterial activity of flavonoid from kepel (Stelechocarpus burahol) leaves against Staphylococcus epidermidis. Int J Pharm Pharm Sci 2017;9(10):292-296. 